\title{
Ornamental Plant Breeding ${ }^{(1)}$
}

\author{
FLÁVIA BARBOSA SILVA BOTELHO(2), CINTHIA SOUZA RODRIGUES ${ }^{(3)}$ e ADRIANO TEODORO BRUZ|(2)
}

\begin{abstract}
World's ornamental plant market, including domestic market of several countries and its exports, is currently evaluated in 107 billion dollars yearly. Such estimate highlights the importance of the sector in the economy of the countries, as well as its important social role, as it represents one of the main activities, which contributes to income and employment. Therefore a well-structured plant breeding program, which is connected with consumers' demands, is required in order to fulfill these market needs globally. Activities related to pre-breeding, conventional breeding, and breeding by biotechnological techniques constitute the basis for the successful development of new ornamental plant cultivars. Techniques that involve tissue culture, protoplast fusion and genetic engineering greatly aid conventional breeding (germplasm introduction, plant selection and hybridization), aiming the obtention of superior genotypes. Therefore it makes evident, in the literature, the successful employment of genetic breeding, since it aims to develop plants with commercial value that are also competitive with the ones available in the market.
\end{abstract}

Key words: Domestication, germplasm, breeding strategies

\section{RESUMO}

\section{Melhoramento Genético de Plantas Ornamentais}

O mercado mundial de plantas ornamentais, incluindo o mercado interno dos diferentes países e suas exportações, está atualmente avaliado em US\$ 107 bilhões anuais. Essa estimativa evidencia a importância do setor na economia dos países, além do importante papel social, representando, uma das principais atividades geradoras de ocupação, emprego e renda. Para suprir as necessidades deste mercado, tanto mundial quanto nacional, é fundamental um programa de melhoramento genético bem estruturado e sincronizado com as exigências do consumidor. Atividades relacionadas ao pré-melhoramento e melhoramento tanto convencional quanto por meio de técnicas biotecnológicas são a base para o sucesso na geração de novas cultivares de plantas ornamentais. Técnicas envolvendo cultura de tecidos, fusão de protoplasto e engenharia genética auxiliam sobremaneira às práticas de melhoramento convencional (introdução de germoplasma, seleção de plantas e hibridação) objetivando a geração de genótipos superiores. Sendo assim, fica evidente, na literatura, o sucesso do emprego do melhoramento genético, objetivando a obtenção de plantas que tenham valor comercial e que sejam competitivas com os materiais já disponíveis no mercado.

Palavras-chave: Domesticação, germoplasmas, estratégias de melhoramento.

\section{INTRODUCTION}

World's ornamental plant market is expanding. Dynamism and constant need for innovation are remarkable characteristics of such market. In this scenery, Brazilian market can be highlighted due to its capacity to supply a massive number of consumers with a great variety of plants with ornamental and landscaping potential use.

The agribusiness of flowers and ornamental plants in Brazil is consistently consolidating a more relevant position in the national agribusiness. It deserves special attention, because this economically growing activity, not only aggregates a high potential for expansion, but also has an important social role representing one of the main activities which contributes to income and employment for micro and small producers throughout the country.

Brazilian floriculture exports totaled U\$35.6 million, increasing its sharing on the Gross Domestic Product (GDP) in the latest years. It has been achieved by the production of flowers nationwide to supply domestic and external markets. Recently, in a survey carried out by Junqueira and Peetz (2014), it was observed that the supply chain of flowers and ornamental plants accumulated an increase of $8.3 \%$ in the revenue of 2013 compared to the results of the previous year. The total value reached $\mathrm{R} \$ 5.22$ billion and the first estimates for 2014 indicate a total of $\mathrm{R} \$ 5.64$ billion. That would represent an increase of $8 \%$ compared to 2013. Such results allow optimism, especially because there is a trend of stagnation in the Brazilian economic scenery. Nevertheless the sector imports is still considered elevated.

It is important to highlight that the increase in production and commercialization of ornamental plants in Brazil has only been possible due to the applied researches in the fields of genetics, physiology and nutrition, which has contributed to the development of new technologies and the increase of yield per area. Those are essential characteristics in order to achieve economic feasibility of

\footnotetext{
(1) Trabalho recebido para publicação em 21/11/2014 e aprovado em 05/03/2015

(2) Departamento de Agricultura, Universidade Federal de Lavras-MG, Lavras-MG. *autor correspondente: flaviabotelho@dag.ufla.br;

${ }^{(3)}$ Departamento de Biologia, Universidade Federal de Lavras-MG, Lavras-MG
} 
the commercial production and the development of more resistant varieties, which are adapted to distinct climatic conditions.

Hence it is plausible to assume that in order to fulfill both domestic and external market needs, it is indispensable a genetic improvement program, which is connected with consumers' demands and aims to discover plants with commercial value that are also competitive with the ones currently available in the market. In other words, the market must see the new plants as real innovations that offer some advantage compared to the current commercial hybrids (FILLIETTAZ, 2007).

\section{DOMESTICATION AND PRE-BREEDING}

Plant domestication consists of an evolutionary process, conducted by the man, in order to obtain a new kind of plant that fulfills human needs (SMITH, 1995). It began more than ten thousand years ago and it probably has happened in 8 different ecological regions at least. Domesticated plants are genetically different from their wild ancestors. They are not able to reproduce in the nature without the human intervention (VAVILOV, 1951; FLINT-GARCIA, 2013).

Domesticated plants present several morphological modifications if compared with the wild species. Harlan (1992) named these changes "Domestication Syndrome". Amongst such modifications we can cite the increase in the fruit size and seeds; the increase in the number of seeds by flowerage pruning; reduction or loss of, not only toxic and bitter substances, but also of the structure related to the natural protection as thorns and spines; loss of seed dormancy which allows a more uniform germination; inefficiency in the mechanism of natural dispersion of the seeds: in some cultivated plants, the grains remain attached to the ears, which requires human intervention; reduced cross-pollination rate, which characterizes autogamous plants; reduction in the lifecycle of the plants, changing from perennial to annual; and presence of both genders in one individual, that is, predominance of monoecious plants (SAWAZAKI PATERNIANI, 2004).

There are evidences that, since the ancient times, species as the white lily (Lilium candidum) were already cultivated for ornamental purposes, interior design and outdoor landscaping. Ornamental species were selected by men taking into account visual attractive characteristics as flashy, colorful, perfumed inflorescence and flowers; foliage with exotic colors and textures; distinct stalk shapes; or the general appearance. Along the years, men realized it was possible to improve desirable qualities in a plant by crossing superior individuals. Thus new varieties emerged with new colors, larger and more durable flowers, and higher resistance to predators and climatic diversity. Roses are cultivated for thousands of years in the Middle East. They are no longer presented in their original state, but the immense range of shapes and hybrids obtained along all these years by cultivation are good examples of the human capacity to change nature to fulfill our needs.

Ornamental plant domestication is considered recent, less than 500 years. Nowadays there are still semidomesticated species. It means they have been handled, however no breeding has been employed in such procedure. Several species of orchids, ornamental pineapple, palm trees, Barbados lily (Hippeastrum puniceum), petunias (Petunia spp), Brazilian lily (Alstroemeria caryophyllaea) and other Heliconiaceae with potential for cut flower, among others (TOMBOLATO et. al.,2004).

According to Tombolato (2004), a species can be considered domesticated only after going through genetic and cultural breeding processes. The utilization of the fruit or any other products provided by a species in its natural environment does not imply in domestication. Semidomestication begins when the germplasm is collected and cultivated ex situ. The "Arboreto Monjolinho", a collection of trees and palm trees located in the botanical garden of the Agronomic Institute (JBIAC), is a good example of it. In this particular case, there is an adaptation of the species to a new environment and a consequent change of the allelic frequencies. Only the individuals adapted to the new conditions are capable of surviving.

The breeding process, indispensable in domestication, may be facilitated by pre-breeding. Pre-breeding consists of the identification of genes or characters of interest in exotic germplasm or populations which were not submitted to any breeding process. Posteriorly, the incorporation of elite adapted germplasm is performed (NASS e PATERNIANI, 2000).

Pre-breeding works as a link between vegetable genetic resources and breeding. It favors the identification of potential genes, the formation of new populations, the improvement of knowledge about germplasms, and the enhancement of the utilization of vegetable genetic resources in breeding programs (DUVICK, 1990).

Activities related to pre-breeding include collection, introduction, conservation and characterization of the germplasm banks - BAGs (MONTALVÁN et. al., 1999). Such activities turn possible the genotype selection among the progenies resulted from hybrid and interspecific crossings. They use wild and native species, which allows a great number of combinations of the ornamental desirable characteristic, as well as the inclusion of genes related to resistance and tolerance to the adverse factors of the cultures.

In this context, ornamental plant genetic resources are extremely rich and varied, what makes pre-breeding strategically useful. According to Doebley et al. (1990), pre-breeding is restricted by the lack of information in the germplasm banks. The lack of data related to passport as well as to agronomic, genetic, and botanical characterization affects considerably the appropriate usage of the material for breeding purposes. It is often true for the ornamental species since there are few describers to be applied to the variability kept in a germplasm bank.

In Brazil, the institutions in charge of the germplasm banks are the Agronomic Institute of Campinas (IAC), the Botanical Garden of São Paulo, Forest Institute, Unicamp, Esalq, and Embrapa.

IAC has been the pioneer institution in domestication 
and ornamental plant breeding in Brazil. Since 1970, it introduces and researches ornamental plants, accumulating an extensive institutional patrimony with approximately 700 species of palm trees, 2,000 of arboreal and countless ornamental herbaceous. In 1997, it was officially launched the first ornamental cultivar of the country: the Astral Anthurium. After this, many other selections were provided to producers.

\section{BREEDING STRATEGIES APPLIED TO ORNAMENTAL PLANTS}

The most challenging about genetic breeding is to develop better cultivars to compete with the current ones available in the market (BORÉM AND MIRANDA, 2009). The selection of ornamental plants with superior quality must consider the ornamental characteristics as color, size and flower proportionality as well as the vegetal strength; the agronomic characteristics as fast and vigorous growing, fast flourishing, flower durability, response to fertilization, facility of cultivation and propagation, resistance to plagues and diseases, adaptability to different cultivation regions; and the innovative aspect of the cultivar, which makes it interesting commercially and productively (CARDOSO, 2010).

The importance of the breeding programs must be highlighted in order to align the conventional selection practices and biotechnological tools. Therefore it would be possible to reduce the time to develop a cultivar, to broaden the possibilities related to the use of genetic variability, and to increase the selection efficiency. Nevertheless it is necessary that such biotechnological techniques are integrated to conventional breeding in order to achieve a higher success rate for the obtention of novel ornamental species genotype. Next in this study, conventional breeding practices and biotechnological tools employed to ornamental plants will be presented.

\subsection{Conventional breeding tools applied to}

\section{ornamental plants}

During the obtainment process of superior ornamental plant varieties, some plant breeding methods deserve special attention: germplasm introduction, plant selection and hybridization.

\section{Germplasm introduction}

Germplasm introduction, also known as either plant introduction or lines, is considered a breeding method and still contributes significantly to the obtention and recommendation of superior ornamental plants. As an example, we can cite the Brazilian commercial orchids. Only 10\% are endemic (CARDOSO, 2010). The breeding program of bromeliads has also begun based on the germplasm introduction in 1993 at IAC.

This breeding method can be seen by two different approaches: the first refers to the use of this method as a source of genetic variability, and the second, to the direct utilization of germplasm in a specific area.
In crossing, the germplasm use as a source of genetic variability is a daily activity performed at any breeding program. The breeder, supported by the literature, identifies the target genotypes and requests it to the owner of the genetic material or to the germplasm bank. Introduction can be done using national or imported germplasm. The latter must observe legal procedures. The current cultivar protection law does not restrict the utilization of foreign germplasm for hybridization in Brazil.

The germplasm introduction method for direct recommendation of cultivation in specific regions has often been used in ornamental plant breeding. In this case, genotypes are introduced and submitted to evaluations in experiments with replications in several representative locations of the area before its recommendation. It emphasizes the importance of the breeder's role, since he must use his skills to identify the genotypes to be recommended to producers, even though he has not developed the material himself. Currently the cultivar protection law allows the utilization of germplasm introduction with material provided by another Brazilian breeding program, since the involved institutions establish a formal agreement. It is a requirement to be observed before the material can be launched into the market. (RAMALHO et. al., 2005)

\section{Plant selection}

Selection is the process in which individuals with superior characteristics are favored to reproduction over the others in a genetically variable population, yielding, therefore, a higher number of descendants. Selection exists not only at the evolutionary level (Natural Selection), but also at the breeder's work level. It should not be forgotten that artificial selection, performed in the breeding programs, is applied to the autogamous as well as to the allogamous plants (BUENO et. al., 2006).

Bueno et. al. (2006) asserts that selection through an empiric process, based solely on the subtlety and human capacity to perceive certain differences between plants, is a very old process. Knowledge about selection techniques deepened along the centuries as a consequence of the agricultural activities. However only in the late $18^{\text {th }}$ century, plant breeding became more methodic, which majored the efficiency of the selection.

The most significant contribution to clear up the effects of selection was given by Louis de Vilmorin, yet in the $19^{\text {th }}$ century, conceiving a selection method of lines with progeny test. It has been known as "Vilmorin Method" since then. Nonetheless, only in the beginning of the next century, geneticists were able to clarify the origin of variation, which constitutes the basis of selection.

A successful example of the employment of the selection method in ornamental plants is described in Gladiolus. The process was efficient regarding the improvement in the phenotypic characteristics related to the increase of the commercial quality (ornamental potential) under high temperature and luminosity variation. It also presented 
benefits in the characters that aim to facilitate handling, packing and storage.

\section{Hibridization}

The existence of genetic variability constitutes "conditio sine qua non" for the conduction of a breeding program of any species. Frequently, in extreme situations, the germplasm in certain species does not entirely fulfill the breeder's goals or the producers' and consumers' needs. In other sceneries, it is possible to find isolated desirable characteristics in distinct varieties. In these cases, the breeder's work consists in gathering new genotypic combinations that take in consideration those manifested characteristics in existing genotypes from the same species. The obtention of such gene combinations is done through crossing. Hybridization is, thus, the process by which recombination of genes is originated. Among them, some might be highly favorable when attempting to achieve new cultivars that present superior agronomical characteristics.

Considering the ornamental plants, the major objective of hybridization is to obtain innovative cultivars, which present great commercial value, market differentials to overcome competition, cultural advantages, and capacity to generate variability in order to provide new phenotypic combinations, mainly in the flower organs.

In most of the ornamental species, crossing is artificially performed by the emasculation process. That is, a variety is used as the male genitor (pollen provider) and another as the female genitor (pollen receiver), since the majority of the plants are androgynous. The emasculation process comprises the removal of the anthers from the genitor used as the mother before proceeding with the artificial pollination.

Besides the correct choice of the genitors, the breeder's ability to select weeping plants is crucial. Hence the plant breeder must deeply know the culture he is working on, in order to evaluate it, visually, to ensure its effectiveness for the morphological and physiological characters, which characterize the good genotypes. This natural capacity of perception cannot be exclusive. It is convenient to proportionate favorable conditions to the plants, so the characters can be expressed. It can be done by the employment of special techniques, according to the aspired aim. That is the case, for instance, of the resistance to diseases or to determined groups of pathogens, becoming necessary the artificial inoculation with the intention to figure out resistant varieties when it is not naturally affected.

\subsection{Biotechnological techniques applied to ornamental plant breeding}

\section{Polyploidy in ornamental plant breeding}

Polyploidy refers to one of the principal phenomena comprised in the plant evolution process. It is defined by many authors as the variation of the somatic number of chromosomes present in a species, in such way that, instead of two sets of chromosomes in the somatic cells (two genomes) and, correspondingly, one genome in the somatic cells, it is possible to find different quantities. Thus, some specimen might have its somatic tissue constituted by cells with 4, 6, 8 genomes, or even, in some situations, by an odd number of chromosome sets (BUENO et. al., 2006).

The artificial duplication of the number of chromosomes of certain ornamental species is an important instrument for breeding programs, because it usually favors the enlargement of commercially interesting organs. In addition, it makes possible that sterile hybrids (due to pairing flaws) may form active gametes again and reproduce sexually. In ornamental plants, such as orchids, that is particularly important for increasing the size of the flower and for intensifying perfume and colorfulness. Moreover it contributes to restore the fertility of rare hybrids (GRIESBACH, 1985; GAO et. al., 1996; SILVA et. al., 2000).

Bueno et. al. (2006) also state that there are several manners to obtain polyploidy individuals and the most usual way is by using Colchicine, an alkaloid extracted from a plant scientifically named Colchicum autumnale. This substance is easy to handle for being soluble in cold water, alcohol and chloroform. Besides it is quite efficient in low concentrations and may be applied in different parts of the plant as seeds, gems, bulbs, roots, leaves, seedlings in aqueous solutions, or even glycerin and lanolin pulp, among others. Colchicine seems to affect just the cells in process of meiotic division. This fact impedes the achromatic fuse formation.

Chromosome duplication is capital as part of the development of enhanced commercial varieties and hybrid orchids (BLUMENSCHEIN, 1957). Polyploid plants are commonly used by ornamental plant breeders in crossings, due to the advantageous characteristics that are observed in the flowers. Therefore, it can be doubtless stated that the cytogenetic analysis for orchids is vital as an instrument for a successful ornamental plant breeding program.

Plenty of morphological and physiological effects are expected from polyploidization. The instant result is the magnification of the cell size, as a consequence of the increase in the size of the cell nucleous. That leads to a reduction in the number of cellular divisions during its development. The well-known "gigas effect" is commonly observed in organs featured by a highly-determined standard of growth, such as flowers and seeds (VICHIATO, 2005).

The general characteristics presented by polyploid plants are thicker and firmer flowers and petals with darker colors, less frequent but bigger stomata, less intense ramification, meiotic cycle retardation and, consequently, flourishing and fructification retardation (BRIEGER, 1992; DRESSLER, 1993;TOSCANO and MORAES, 2002; FAM et. al. 2003).

In the work of Kermani et. al. (2003), the induction of chromosome duplication in diploid and triploid rose cultivars obtained tetraploid and hexaploid with significant increase on the leave thickness, intensification of dark-green color and increase of the ratio width/length, in addition to the verification of more petals and higher feasibility for pollen grains in tetraploid plants. 


\section{Employment of protoplast fusion}

Protoplast is the living part of the cell, that is, a cell that has its wall removed. In 1910, it was found that protoplasts kept in solutions with calcium salts could be in contact and eventually merge their content; this process was called protoplast fusion. The discovery that protoplasts can be fused easily led to the development of a genetic methodology that was called somatic hybridization. The importance of somatic hybridization is that sexually incompatible species can be recombined by protoplast fusion, thus enabling the creation of new genetic combinations.

Somatic hybridization opened numerous possibilities for genome manipulations, such as: 1) overcoming sexual incompatibility (LIU et al, 2005; DAVEY et al, 2005); 2) amphidiploid production (JOURDAN and SALAZAR, 1993); 3) transfer of part of the genome of a species to another (LIU et al, 2005); 4) transfer of the cytoplasmic DNA for producing male-sterile plants (LIU et al, 2005; DAVEY et al, 2005).; 5) production of plants resistant to environmental stress or pests and diseases (AUSTIN et al, 1985;. ENDO et al., 1991; GLIMELIUS et al., 1991; BUI et al, 1992;. WOLTERS et al., 1994; WAARA and GLIMELIUS, 1995; HENN et al, 1998;. BINSFELD, 1999; LIU et al, 2005).

Dayer et al. (2005) present positive results in which protoplast fusion, symmetrical or asymmetrical, collaborated in the genetic improvement of many economically important crops such as potatoes, ornamental plants, citrus, brassicas and cereals. Interest in protoplast technology has had a particular focus on generating new somatic hybrids that cannot be produced by conventional hybridization.

Studies have reported the generation of somatic hybrids in ornamental species. Vazquez Tello et al. (1996), in their study, tried to transfer the tolerance against cold from the Lavatera thuringiaca to Hibiscus rosa-sinensis, but failed to regenerate the hybrid plants. Studies involving the use of protoplast fusion technique aiming somatic hybridization, confirms the main limitation of this technique is the precarious development of regeneration methods (HARNING et al., 1991).

Subsequently, Horita et al. (2003) generated fertile somatic hybrid plants between the eastern hybrid lily cultivars Acapulco, Shirotae and formolongi L. cv. Hikucho. In this study, the molecular analysis using CAPS markers and flow cytometry confirmed the somatic hybrid nature of the regenerated plants.

\section{Somaclonal variation}

According to Vieira and Glory (2001), the cultivation of cells, tissues and plant organs in the laboratory comprises a number of steps since the introduction of the explant in vitro, establishment and maintenance of the cultures until shoot regeneration.

The changes resulting from in vitro stress may lead to the appearing of morphological variants, in other words, individuals known as off-type. Larkin and Scowcroft (1981) coined the term somaclonal variation to designate the occurrence of genetic variants derived from in vitro cell culture. One can extend this definition for any variation of genetic nature, cytogenetic or molecular originated in the early stages of culture (callus induction, for example) or during the shoot regeneration phase. Therefore, it is always associated with the plant regeneration process from in vitro procedures (VIEIRA and GLORY, 2001).

Scientists have warned about the potential variability generated by in vitro culture to be explored by breeding programs. The literature documents very clearly that potential. The generation of genetic diversity through in vitro culture has been sought in species with genetic erosion resistance or aiming to generate resistance to salinity, pests and pathogens, submitting, for example, the crops to the presence of fungal toxins, high concentrations of salts, and aluminum ions among others. In combination with conventional mutation induction techniques, the generation of new variants, followed by selection and cloning, may result in very promising genotypes.

It is known that more than 1700 mutants involving 154 agricultural and ornamental species produced through induced mutation followed by selection, have been officially released. Excellent results were obtained in alstroemeria, begonia, chrysanthemum, carnation, dahlia and streptocarpus (MALUSZYNSKI et al., 1995).

The occurrence of somaclonal variation is described in various cultures of agronomic interest. Floriculture can benefit from this variability, obtaining new varieties. Rodrigues (2008), successfully obtained, somaclonal variation in plantlets of Heliconia bihai cv. Lobster Claw I. After induction of variation, it was selected at random and compared with 2,000 plants originated from rhizomes to form the test. In the calculation of the percentage of variants it was evaluated the characteristics: plant height, shape and color of leaves and pseudostem. He found that there are three types of somaclonal variants was observed (Variation of Chlorophyll in Leaf), VPB (Porte variant Low) and vCPP (Colour Variant and Pseudostem and petiole), the latter with ornamental potential. The somaclonal variation rate for Heliconia bihai cv Lobster Claw I, under the proposed conditions, was $61.40 \%$.

\section{Interspecific hybridization and intergeneric}

The search for new species of ornamental plants has grown in recent years, especially those marked by originality, durability and beauty. Innovation in floriculture can occur by identifying new genetic materials with ornamental potential, or the generation of new hybrids from breeding programs (Souza, 2013).

Hybridization is an important source of genotypic variation (Vervaeke et al., 2004). Interspecific and intergeneric hybridizations allow you to create genotypes with new combinations of shapes and colors (Vervaeke et al, 2004) exercising strategic role in the development of new ornamental varieties. The successful interspecific hybridization and intergeneric depends on the viability of crossings and obtention of viable seeds.

Studying the use of interspecific hybridization in bromeliad, Souza (2013) examined the possibility of generating new hybrids, however, comments that other 
morphological evaluations, cytogenetic, molecular and market are necessary to prove the ornamental potential of hybrids.

The interspecific and intergeneric hybridization contributed significantly to the development of ornamental plants. His participation was decisive, producing a large number of species, and between orchids, roses, rhododendrons, dahlias, gladioli and violets.

\section{Genetic engineering and ornamental plants}

In some ornamental species, the development of new genotypes by means of hybridization is difficult and time consuming or cannot be used when genotypes are completely sterile, as in orchids (DA SILVA et al., 2011). In such cases, the transgenics would be an efficient alternative to obtain improved cultivars.

The transgenic organisms are those whose genome has been modified with the purpose of giving them new feature or change any existing feature through the introduction or elimination of one or more genes by genetic engineering (MARINO et al., 2004). The choice of method for introducing exogenous genes is determined according to the plant species. The methods based on Agrobacterium tumefaciens are the most simple and efficient, but practically limited to dicots, except for a few, as recalcitrant (LACORTE and MANSUR, 1993). The option for the genetic manipulation of these species and monocots is often found in the direct transfer of techniques such as micro bombardment and electroporation, through which it has been already achieved, for example, transgenic corn, cane sugar and rice (CHRISTOU, 1992).

The challenges associated with processing of ornamental plants are the same as those faced in any plant species. These include resistance to infection of monocotyledons by Agrobacterium species and transformation efficiency of the difficulties associated with the regeneration of plant tissue (CHANDLER and SANCHEZ 2012).

The transgenics potentiate a new revolution in agriculture, the possible applications of genetic modification of plants are huge, these applications benefit the producer, as it includes features that improve the agronomic performance of plants. To date, several genes were stably introduced into plants, conferring resistance to herbicides, fungi, bacteria, viruses and insects. There are other very significant examples, such as genes related to product quality and nuclear male sterility, an important feature for hybrid production programs.

In the case of ornamental plants, the market has shortage of genotypes with excellent qualities of postharvest, to keep the fragrance after cutting, disease resistant, more productive and more durability from vegetative parts. Using these techniques, genetic modifications can be introduced characteristics of the new genetically modified varieties (CHANDLER and SANCHEZ, 2012).

Modifying the color of the flowers dominates researches related to transgenic, due to the fact that in many ornamental plants the colors of the flowers are limited by genetics of plant species (DEBENER and WINKELMANN, 2010) and, according to Tanaka et al. (2010), genetic modification is the only effective way to overcome this limitation.

The color of the flower marker gene was first demonstrated more than 20 years ago (MEYER et al., 1987) and in 1993, the encoding gene to a flavonoid 3'5'-hydroxylase was isolated (HOLTON et al., 1993 ), providing essential tool for changing the color of carnation flower (Dianthus caryophyllus) and rose (Rosa hybrida).

Currently, the key genes for the anthocyanin, carotenoid and flavonoid, the transcription factors of the biosynthesis and metabolism pathways which allows flower color modification in many ways are already known (NISHIHARA and NAKATSUKA, 2011; TANAKA et al, 2010).

\section{REFERENCES}

AUSTIN, S.; BAER, M., EHLENFELDT, M.; KAZMIERCZAK, P.J.; HEGELSON, J.P. Intra-specific fusion in Solanum tuberosum. Theoretical and Applied Genetics, v.71, p. 172-175, 1985.

BINSFELD, P.C. Production and characterization of interspecifc transgenic plants in the genus Helianthus using microprotoplast techinique. Göttingen. Cuvillier Verlag, 1999.

BLUMENSCHEIN, A. Estudos citológicos na família Orchidaceae. Universidade de São Paulo, Piracicaba, 1957.

BORÉM, A.; MIRANDA, G.V. Melhoramento de plantas. 5ed. Viçosa: UFV, 2009. 529p.

BOURQUE, J.E. Antisense strategies for genetic manipulations in plants. Plant Science. v.105, p.125-149, 1995.

BRIEGER, A. H. N. Caracterização morfológica e estudo da anatomia foliar de populações de Epidendrum nocturnum Jacq. (Orchidaceae). 1992. 79f. Universidade Estadual Paulista, Jaboticabal.

BUENO, L.C. de S.; MENDES, A.N.G.; CARVALHO, S.P. Melhoramento genético de plantas: princípios e procedimentos. 2.ed. Lavras: UFLA, 2006. 319p.

BUI, P.T.; JENNS, A.E.; SCHNEIDER, S.M.; DAUB, M.E. Resistance to tabaco mosaic virus and Meloidogyne arenaria in fusion hybrids between Nicotina tabacum and an $N$. rapanda $x N$. sylvestris hybrid. Phytopathology, v.82, p.1305-1310, 1992.

CARDOSO, J.C. Laeliocattleya 'Brazilian Girl Rosa': cultivar de orquídea para cultivo em vaso. Horticultura Brasileira, Brasília, v.28, n.3, 2010.

CHANDLER, S.F.; SANCHEZ, C. Genetic modification; the development of transgenic ornamental plant varieties. Plant Biotechnology Journal, v.10, p.891-903, 2012. 
CHRISTOU, P. Genetic transformation of crop plants using microprojectile bombardment. The Plant Journal, v.2, n.3, p.275-281, 1992.

Da Silva, J.A.T., Chin, D.P., Van, P.T. and Mii, M. Transgenic orchids. Science Horticulturae, v.130, p.673680, 2011.

DAVEY, M.R.; ANTHONY, P.; POWER, J.B.; LOWE, K.C. Plant protoplasts: status and biothecnological perspectives. Biotechnology Advances, v.23, p.131-171, 2005.

DEBENER, T.; WINKELMANN, T. Ornamentals. In Genetic Modification of Plants, Biotechnology in Agriculture and Forestry 64 (Kempken, F. and Jung, C., eds). Heidelberg: Springer-Verlag, p.369-391, 2010.

DOEBLEY, J.; STEC A.; WENDEL J.; EDWARDS, M. Genetic And Morphological Analysis Of A Mayze-Teosinte F2 Population: Implications For The Origin Of Maize. Proceedings of the National Academy of Science, v.87, n.24, p.9888-9892. 1990

DRESSLER, R.L. Phylogeny and classification of the orchid family. Portland: Dioscorides Press, 1993. v.1, $314 \mathrm{p}$.

DUVICK, D.N. Genetic enhancement and plant breeding. In: Janick, J.; Simon, J.E. (Eds.). Advances in new crops. Portland: Timber Press, 1990. p.90-96.

ENDO, T.; HAMAGUCHI, N.; ERIKSSON, T.; YAMADA, Y. Alkaloid biosynthesis in somatic hybrids of Duboisia leichhardtii F. Muell. and Nicotina tabacum L. Planta, v.48, p.505-510, 1991 .

FAM, L. Y.; THAMEA, A.; WING,Y. T. Influence of the increase of ploidy levels (from $2 n$ to $4 n$ ) on the physical attributes of Ionocidium popcorn. Singapore Botanic Garden: Singapore, 2003. Disponível em: http://staf. science.nus.edu.sg/ scilooe/srp- 2003/sci-paper/botanic/ research. Acesso em: 2 de Março de 2015.

FCO - Federação Catarinence de Orquídeas. Acessada em 24 fevereiro, 2015 http://www.fcorquidofilia.com. br/?opcao $=$ con_plantas .

FILliETTAZ, A. Melhoramento Genético de Plantas Ornamentais. Biológico, São Paulo, v.69, n.2, p.95, 2007.

FLINT-GARCIA, S.A. Genetics and Consequences of Crop Domestication Agricultural Research Service, U.S. Department of Agriculture, 301 Curtis Hall, University of Missouri, Columbia, Missouri 65211, United States. 2013.

GAO, S.L.; ZHU, D.N.; CAI, Z.H.; XU, D.R.Autotetraploid plants from colchicine-treated bud culture of Salvia miltiorrhiza Bge. Plant Cell, Tissue and Organ Culture, Netherlands, v.47, n.1, p.73-77, 1996.
GLIMELIUS, K.; FAHLESON, J.; LANDGREE, M.; SJÖDIN, C; SUNBERG E. Gene transfer via somatic hybridization in plant. Tibtech, v.9, p.24-30, 1991.

GRIESBACH, R.J. Polyploidy in Phalaenopsis orchid improvement. The Journal of Heredity, Baltimore, v.76, n.1, p.74-75, 1985.

HARDING, J. ; SINGH, F. ; MOL, J. N. M. Genetics and Breeding of Ornamental Species. 1ed. Dordrecht: Netherland, Kluwer Academic Publishers, 1991.

HENN, H.J.; WINGENDER, R.; SCHNABL, H. Regeneration of fertile interspecific hybrids from cell fusion between Helianthus annus L. and wild Helianthus specie. Plant Cell Reports, v.18, p.220-224, 1998.

HOLTON, T.A., BRUGLIERA, F., LESTER, D.R., TANAKA, Y., HYLAND, C.D., MENTING, J.G., LU, C.Y., FARCY, E., STEVENSON, T.W. AND CORNISH, E.C. Cloning and expression of cytochrome P450 genes controlling flower colour. Nature, 366, 276-279, 1993.

NISHIHARA, M.; NAKATSUKA, T. Genetic engineering of flavonoid pigments to modify flower color in floricultural plants. Biotechnology Letters, v.33, n.3, p.433-441, 2011.

HORITA M, MOORHASHI H, KOMAI F. Production of fertile somatic hybrid plants between Oriental hybrid lily and Lilium formolongi. Planta, v.217, p.597-601, 2003.

IAC- ISTITUTO AGRONOMICO DE CAMPINAS http:// Www.iac.sp.gov.br/areasdepesquisa/horticultura/historico. php. Acessado em 24 de fevereiro de 2015.

JOURDAN, P.; SALAZAR, E. Brassica carinata resynthesized by protoplast fusion. Theoretical and Applied Genetics, v.86, p.567-572, 1993.

JUNQUEIRA, A.H.; PEETZ, M.S. Balanço do comércio exterior da floricultura brasileira. Hórtica - Contexto \& Perspectivas. 2014.

KERMANI, M.J.; SARASAN ,V.; ROBERTS, A.V.; YOKOYA, K.; WENTWOETH, J.; SIEBER, V.K. Oryzalininduced chromosome doubling in Rosa and its effect on plant morphology and pollen viability. Theoretical and Applied Genetics, v.107, n.7, p.1195-1200, 2003.

LACORTE, C.; MANSUR, E. Transferência de genes através da Agrobacterium tumefaciens: avaliação da Compatibilidade patógeno-hospedeiro. ABCTP Notícias, n. 21, p.2-7, 1993.

LARKIN, P.J.; W.R. SCOWCROFT. Somaclonal variation: a novel source of variability from cell cultures for plant improvement. Theoretical and Applied Genetics, v.60, p.197-214. 1981. 
LIU, J.; XU, X.; DENG， X. Intergeneric somatic hibridization and its application to crop genetic improvement. Plant Cell, Tissue and Organ Culture, v.82, p.19-42, 2005.

MALUSZYNSKI M., VAN ZANTEN L., ASIR A., BRUNNER H., AHLOOWALIA B., ZAPATA F.J., WECK E. Mutation techniques in plant breeding. Proc. Induced Mutations and Molecular Techniques for Crop Improvement. FAO/IAEA, Viena, 1995. p.489-504.

MARINHO, C.L.C.; MINAYO-GOMEZ, C. Decisões conflitivas na liberação dos transgênicos no Brasil. São Paulo em Perspectiva, São Paulo, v.18, n.3, p.96-102. 2004.

MEYER, P., HEIDEMANN, I., FORKMANN, G. AND SAEDLER, H. A new petunia flower colour generated by transformation of a mutant with a maze gene. Nature, v.330, p.677-678, 1987.

MONTALVÁN, R.; FARIA, R.T. Variabilidade genética e germoplasma. In: DESTRO, D.; MONTALVÁN, R. Melhoramento genético de plantas. Editora UEL: Londrina, 1999. p.27-38.

NASS, L.L.; PATERNIANI, E. Pre-breeding: a link between genetic resources and maize breeding. Scientia Agricola, Piracicaba, v.57, p.581-587, 2000.

RAMALHO, M.A.P.; ABREU, A.F.B.; SANTOS, J.B. Genetic progress after four cycles of recurrent selection for yield and grain traits in common bean. Euphytica, v.144, n.1/2, p.23-29, 2005.

RODRIGUES, P.H.V. Somaclonal variation in micropropagatedHeliconia bihai cv. Lobster Claw I plantlets (Heliconiaceae). Scientia Agrícola, Piracicaba, v.65, n.6, p. 681-684, 2008.

SAWAZAKI, E.; PATERNIANI, E. M.A.G.Z. Evolução dos cultivares de milho no Brasil. In: GALVÃO, J.C.C.; MIRANDA, G.V. (Eds.). Tecnologias de Produção de Milho. UFV:Viçosa, 2004. p.55-83.

SILVA, P.A.K.X.M.; CALLEGARI-JACKES, S.; ZANETTINI, M.H.B. Induction and identification of polyploids in Cattleya intermedia Lind. (Orchidaceae) by in vitro techniques. Ciência Rural, Santa Maria, v.30, n.1, p.105-111, 2000.

SMITH, B.D. The emergence of agriculture. New York: W. H. Freeman. 1995.

SOUZA, E. H. Reprodução e Hibridação interespecífica e intergenérica em bromeliáceas com potencial ornamental. Tese de Doutorado. Centro de Energia Nuclear na Agricultura, Universidade de São Paulo, Piracicaba, 2013.
TANAKA, Y., BRUGLIERA, F., KALC, G., SENIOR, M., DYSON, B., NAKAMURA, N., KATSUMOTO, Y. AND CHANDLER, S. Flower color modification by engineering of the flavonoid biosynthetic pathway: practical perspectives. Bioscience. Biotechnology. Biochemistry. v.74, p.1760-1769, 2010.

SILVA, J.T. Orchids: advances in tissue culture, genetics, phytochemistry and Transgenic biotechnology. Floriculture and Ornamental Biotechnology, v.7, v.1, p.1-52, 2013.

TOMBOLATO, A.F.C; VEIGA, R.F.A., BARBOSA, W., COSTA A.A., JÚNIOR, R.B.; PIRES, E.G. Domesticação e pré-melhoramento de plantas: I. Ornamentais. Informações técnicas. 2004

TOSCANO, L.A. B.; MORAES, M. M. Saiba mais sobre orquídeas. [on line] Disponível na Internet via http://www. jbrj.gov.br/ saibamais/orquideas. Acesso em: 2 de Março de 2015.

VAVILOV, N.I A origem, variação, imunidade e reprodução das plantas cultivadas: escritos selecionados de NI Vavilov, traduzido por K. Starr Chester. Chronica Botanica, v.13,n.1-6, p. 14-54. 1951.

VAZQUEZ-TELLO A, F OUELLET, SARHAN F. baixa temperatura fosforilação estimulada-regula a ligação de factores nucleares para o promotor de wcs 120 , um gene específico frio trigo. Mol Gen Genet.1998.

VERVAEKE, I; DELEN, R.; WOUTERS, R. DEROOSE, R.; DE PROFT, M. P. Division of the generative nucleus in cultured pollen tubes of the bromeliaceae. Plant Cell, Tissue na Organ Culture, Dordrecht, v. 76, p. 17-28, 2004.

VICHIATO M.R. M. e VICHIATO M. e CASTRO D.M. et al. Introdução de tetraploides e alongamento de plantas Dendrobium nobile Lindl. (Orchidaceae). Tese de Doutorado, Lavras: UFLA, 2005.

VIEIRA, M.L.C; APPEZZATO-DA-GLÓRIA, B. Fundamentos e aplicações da cultura de tecidos no melhoramento. In: NASS, L. L.; VALOIS, A. C. C.; MELO, I. S.; VALADARES-INGLIS, M. C. Recursos genéticos e melhoramento. Rondonópolis: Fundação Mato Grosso, 2001. p. 911-938.

WAARA, S.; GLIMELIUS, K. The potential of somatic hybridization in crop breeding. Euphytica, v. 85, p.217233, 1995.

WOLTERS, A.M.A.; JACONSEN, E.; O'CONNEL, M.; BONNEMA, G.; RAMULU, K.S.; JONG, J.H.DE; WIJBRANDI, J.; KOORNNEEF, M. Somatic hybridization as a tool for tomato breeding. Euphytica, v.79, p.265-277, 1994. 